$1-1-1994$

\title{
Plant Competition In Relation To Neighbor Biomass: An Intercontinental Study With Poa Pratensis
}

R.J. Reader

S.D. Wilson

J.W. Belcher

J. B. McGraw

Follow this and additional works at: https://researchrepository.wvu.edu/faculty_publications

\section{Digital Commons Citation}

Reader, R. J.; Wilson, S. D.; Belcher, J. W.; and McGraw, J. B., "Plant Competition In Relation To Neighbor Biomass: An Intercontinental Study With Poa Pratensis" (1994). Faculty Scholarship. 950.

https://researchrepository.wvu.edu/faculty_publications/950 


\title{
Plant Competition in Relation to Neighbor Biomass: An Intercontinental Study with POA Pratensis
}

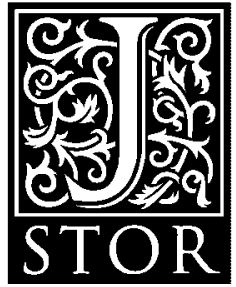

\author{
R. J. Reader; S. D. Wilson; J. W. Belcher; I. Wisheu; P. A. Keddy; D. Tilman; E. C. \\ Morris; J. B. Grace; J. B. McGraw; H. Olff; R. Turkington; E. Klein; Y. Leung; B. \\ Shipley; R. van Hulst; M. E. Johansson; C. Nilsson; J. Gurevitch; K. Grigulis; B. E. \\ Beisner \\ Ecology, Volume 75, Issue 6 (Sep., 1994), 1753-1760.
}

Stable URL:

http://links.jstor.org/sici?sici=0012-9658\%28199409\%2975\%3A6\%3C1753\%3APCIRTN\%3E2.0.CO\%3B2-W

Your use of the JSTOR archive indicates your acceptance of JSTOR's Terms and Conditions of Use, available at http://www.jstor.org/about/terms.html. JSTOR's Terms and Conditions of Use provides, in part, that unless you have obtained prior permission, you may not download an entire issue of a journal or multiple copies of articles, and you may use content in the JSTOR archive only for your personal, non-commercial use.

Each copy of any part of a JSTOR transmission must contain the same copyright notice that appears on the screen or printed page of such transmission.

Ecology is published by The Ecological Society of America. Please contact the publisher for further permissions regarding the use of this work. Publisher contact information may be obtained at http://www.jstor.org/journals/esa.html.

Ecology

(C1994 The Ecological Society of America

JSTOR and the JSTOR logo are trademarks of JSTOR, and are Registered in the U.S. Patent and Trademark Office. For more information on JSTOR contact jstor-info@umich.edu.

CC2003 JSTOR

http://www.jstor.org/

Fri Feb 21 13:06:40 2003 


\title{
PLANT COMPETITION IN RELATION TO NEIGHBOR BIOMASS: AN INTERCONTINENTAL STUDY WITH POA PRATENSIS ${ }^{1}$
}

\author{
R. J. READER \\ Department of Botany, University of Guelph, Guelph, Ontario, Canada N1G 2W1
}

S. D. WILSON

Department of Biology, University of Regina, Regina, Saskatchewan, Canada S4S OA2

J. W. Belcher, I. Wisheu, AND P. A. Keddy

Department of Biology, University of Ottawa, Ottawa, Ontario, Canada K1N $6 \mathrm{N5}$

\section{TILMAN}

Department of Ecology and Behavioral Biology, 1987 Buford Circle, University of Minnesota, St. Paul, Minnesota 55108-6097 USA

\section{E. C. MORRIS}

School of Biological Science, University of New South Wales, P.O. Box 1, Kensington, New South Wales, 2033 Australia

\section{J. B. GRACE ${ }^{2}$}

Department of Botany, Louisiana State University, Baton Rouge, Louisiana 70803 USA

\section{J. B. McGraw}

Biology Department, West Virginia University, Morgantown, West Virginia 26506 USA

H. OLFF ${ }^{3}$

Laboratory for Plant Ecology, University of Groningen, P.O. Box 14, 9750 AA Haaren, The Netherlands

R. Turkington, E. KLeIN, AND Y. LEUNG

Department of Botany, University of British Columbia, Vancouver, British Columbia, Canada V6T 1Z4

B. SHIPLEY

Department of Biology, University of Sherbrooke, Sherbrooke, Quebec, Canada J1K 2RI

R. VAN HULST

Biology Department, Bishops University, Lennoxville, Quebec, Canada J1M $1 Z 7$

M. E. JOHANSSON AND C. NiLSSON

Department of Ecological Botany, University of Umeå, S-901 87, Umeå, Sweden

J. GuREVITCH

Department of Ecology and Evolution, State University of New York, Stony Brook, New York 11794-5245 USA

\section{K. GRIGULIS}

Ecosystems Dynamics Group, Research School of Biological Sciences,

G.P.O. Box 475, Canberra, A.C.T. 2601 Australia

\section{B. E. BEISNER}

Department of Biology, University of Calgary, Calgary, Alberta, Canada T2N 1N4

Abstract. A standardized neighbor removal experiment was conducted in 12 plant communities located on three continents to test the null hypothesis that competition intensity (CI) was independent of the amount of plant biomass present. Six plots were chosen in each community to cover the range of local variation in plant biomass. In each plot the relative growth rate (RGR) of transplanted Poa pratensis (Poaceae) seedlings was compared in the presence and absence of neighbors. Neighbors were removed experimentally using

\footnotetext{
${ }^{1}$ Manuscript received 3 September 1993; revised 5 October 1993; accepted 29 November 1993; final version received 20 January 1994.

2 Present address: National Wetlands Research Center, 700 Cajun Dome Boulevard, Lafayette, Louisiana 70506 USA.

${ }^{3}$ Present address: Department of Terrestrial Ecology and Nature Conservation, Wageningen Agricultural University, Bornsesteeg 47, 6708 PD Wageningen, The Netherlands.
} 
herbicide. Removing neighbors increased RGR of transplants significantly in most plots. $\mathrm{CI}$ increased with an increase in the amount of neighbor biomass present in one community where the range of neighbor biomass was greater than in any other community. In contrast, CI did not change significantly with an increase in neighbor biomass in other communities where the range of neighbor biomass was smaller. For the communities combined, CI was not related to neighbor biomass in a consistent fashion. These results indicate that competition may reduce growth over a wide range of habitat productivity, but the relationship between $\mathrm{CI}$ and neighbor biomass may differ among communities.

Key words: Australia; Europe; habitat productivity; North America; plant competition; Poa pratensis; removal experiment.

\section{INTRODUCTION}

Current theories of plant community organization differ in their prediction about the relationship between competition intensity (CI) and habitat productivity. Some theories (Grime 1979, Keddy 1990) predict that competition intensifies as productivity increases because of a corresponding increase in plant biomass. Other theories (Tilman 1988, Taylor et al. 1990) predict that competition does not intensify with an increase in habitat productivity for two different reasons. First, competition for light may intensify with an increase in habitat productivity but competition for soil nutrients and water may be less intense in productive habitats than in unproductive habitats; consequently, total competition should remain relatively constant along a productivity gradient (Newman 1973, Grubb 1985, Tilman 1988). Second, competition intensity depends on the ratio of resource supply to demand and this ratio may be unrelated to habitat productivity (Taylor et al. 1990).

A number of neighbor removal experiments have been conducted to test these conflicting predictions. In each experiment the response of a target plant to removal of its neighbors was compared at several positions on a productivity gradient. Experimental results have been inconsistent. In some experiments (e.g., del Moral 1983, Gurevitch 1986, Wilson and Keddy 1986, Reader and Best 1989), the performance of the target plant improved most where habitat productivity was greatest. In other experiments (e.g., Fowler 1990, Wilson and Shay 1990, Wilson and Tilman 1991, 1993), the performance of the target plant improved equally at all levels of productivity.

These experimental results may be inconsistent because CI was measured over different ranges of habitat productivity, using different target species, different experimental designs, and different methods to calculate CI. The chance of detecting a relationship between CI and habitat productivity may have been greater where a wider range of neighbor biomass values was considered. Unfortunately, it is difficult to check this possibility because studies involved different target species and interspecific variation in competitive ability is a potentially confounding factor. In the present study, we used the same target species in a standardized neighbor removal experiment, conducted in 12 plant communities on three continents, to test the null hypothesis that $\mathrm{CI}$ is independent of neighbor biomass. The null hypothesis was tested for each community and for all communities combined. The target species used for the experiment was the perennial grass Poa pratensis L., henceforth called Poa. Poa was chosen for two reasons. First, it is widely naturalized and therefore appropriate for use in an intercontinental experiment. Second, its response to neighbor removal did not change significantly across local productivity gradients in previous studies (DiTommaso and Aarssen 1991, Wilson and Tilman 1991). Whether response of such a species to neighbor removal is independent of neighbor biomass over a wide range of habitat productivity also needs to be tested.

The theories mentioned above do not state explicitly how CI should be calculated. Consequently, CI has been equated with the absolute reduction in plant performance due to neighbors (e.g., plant growth rate without neighbors minus plant growth rate with neighbors) or with the relative reduction in plant performance due to neighbors (e.g., difference in plant growth rate without neighbors and with neighbors, divided by plant growth without neighbors) (Keddy 1989, Campbell and Grime 1992, Grace 1993, Turkington et al. 1993). A potential limitation of using the absolute index of CI in this case is that index values may increase with habitat productivity not only because competition intensifies as productivity increases (i.e., plant performance declines where neighbors are present, while performance is constant with neighbors absent) but also because there may be fewer environmental constraints on plant performance as productivity increases and plant performance may improve where neighbors are absent while performance is constant with neighbors present. The relative index of CI allows for possible interhabitat differences in plant performance where neighbors are absent by expressing the absolute reduction in plant performance due to neighbors relative to plant performance with neighbors absent. However, a potential limitation of the relative index of $\mathrm{CI}$ is that it may obscure differences in absolute reduction in plant performance due to neighbors. In the present study, both absolute and relative indices of CI were calculated.

\section{METHODS \\ Study sites}

The study was conducted at 12 locations (Table 1). At each location, a site was chosen that was appropriate 
TABLE 1. Aboveground biomass of neighbors and dominant species at study sites, ordered by increasing neighbor biomass. $n=6$ plots.

\begin{tabular}{|c|c|c|c|}
\hline \multirow[b]{2}{*}{ Location } & \multirow[b]{2}{*}{$\begin{array}{c}\text { Range of } \\
\text { neighbor biomass } \\
\left(\mathrm{g} / \mathrm{m}^{2}\right)\end{array}$} & \multicolumn{2}{|l|}{ Species } \\
\hline & & Four most abundant & $\begin{array}{l}\text { (Mean } \\
\text { Daubenmire } \\
\text { score } \dagger\end{array}$ \\
\hline $\begin{array}{l}\text { 1. Guelph, Canada } \\
\left(43^{\circ} 33^{\prime} \mathrm{N}, 80^{\circ} 10^{\prime} \mathrm{W}\right)\end{array}$ & $26-199$ & $\begin{array}{l}\text { Hieracium floribundum } \\
\text { Poa pratensis } \\
\text { Poa compressa } \\
\text { Viccia cracca }\end{array}$ & $\begin{array}{l}(3) \\
(3) \\
(2) \\
(2)\end{array}$ \\
\hline $\begin{array}{l}\text { 2. Almonte, Canada } \\
\left(45^{\circ} 15^{\prime} \mathrm{N}, 76^{\circ} 15^{\prime} \mathrm{W}\right)\end{array}$ & $61-246$ & $\begin{array}{l}\text { Carex crawei } \\
\text { Sporobolus heterolepis } \\
\text { Danthonia spicata } \\
\text { Sporobolus vaginiflorus }\end{array}$ & $\begin{array}{l}(3) \\
(2) \\
(1) \\
(1)\end{array}$ \\
\hline $\begin{array}{l}\text { 3. Canberra, Australia } \\
\left(35^{\circ} 17^{\prime} \mathrm{S}, 149^{\circ} 11^{\prime} \mathrm{E}\right)\end{array}$ & $121-234$ & $\begin{array}{l}\text { Themeda australis } \\
\text { Stipa falcata } \\
\text { Danthonia carphoides } \\
\text { Taraxacum officinale }\end{array}$ & $\begin{array}{l}(3) \\
(2) \\
(2) \\
(1)\end{array}$ \\
\hline $\begin{array}{l}\text { 4. Morgantown, USA } \\
\left(39^{\circ} 39^{\prime} \mathrm{N}, 79^{\circ} 59^{\prime} \mathrm{W}\right)\end{array}$ & $155-194$ & $\begin{array}{l}\text { Solidago spp. } \\
\text { Danthonia spicata } \\
\text { Vernonia novaboracensis } \\
\text { Impatiens pallida }\end{array}$ & $\begin{array}{l}(-) \\
(-) \\
(-) \\
(-)\end{array}$ \\
\hline $\begin{array}{l}\text { 5. Vancouver, Canada } \\
\left(49^{\circ} 15^{\prime} \mathrm{N}, 123^{\circ} 14^{\prime} \mathrm{W}\right)\end{array}$ & $174-302$ & $\begin{array}{l}\text { Polygonum persicaria } \\
\text { Trifolium repens } \\
\text { Stellaria spp. } \\
\text { Gnaphalium uliginosum }\end{array}$ & $\begin{array}{l}(1) \\
(1) \\
(1) \\
(1)\end{array}$ \\
\hline $\begin{array}{l}\text { 6. Umeå, Sweden } \\
\left(64^{\circ} 12^{\prime} \mathrm{N}, 17^{\circ} 34^{\prime} \mathrm{E}\right)\end{array}$ & $158-384$ & $\begin{array}{l}\text { Geranium sylvaticum } \\
\text { Agrostis capillaris } \\
\text { Cirsium helenoides } \\
\text { Alchemilla } \text { sp. }\end{array}$ & $\begin{array}{l}(3) \\
(2) \\
(2) \\
(1)\end{array}$ \\
\hline $\begin{array}{l}\text { 7. Long Island, USA } \\
\left(40^{\circ} 55^{\prime} \mathrm{N}, 73^{\circ} 8^{\prime} \mathrm{W}\right)\end{array}$ & $163-436$ & $\begin{array}{l}\text { Solidago altissima } \\
\text { Solidago rugosa } \\
\text { Poa annua } \\
\text { Viccia cracca }\end{array}$ & $\begin{array}{l}(-) \\
(-) \\
(-) \\
(-)\end{array}$ \\
\hline $\begin{array}{l}\text { 8. Sawyerville, Canada } \\
\left(45^{\circ} 25^{\prime} \mathrm{N}, 71^{\circ} 30^{\prime} \mathrm{W}\right)\end{array}$ & $237-557$ & $\begin{array}{l}\text { Festuca rubra } \\
\text { Phalaris arundinacea } \\
\text { Agrostis stolonifera } \\
\text { Cerastium arvense }\end{array}$ & $\begin{array}{l}(3) \\
(3) \\
(1) \\
(1)\end{array}$ \\
\hline $\begin{array}{l}\text { 9. Groningen, The Netherlands } \\
\left(53^{\circ} 5^{\prime} \mathrm{N}, 6^{\circ} 40^{\prime} \mathrm{E}\right)\end{array}$ & $81-648$ & $\begin{array}{l}\text { Agrostis stolonifera } \\
\text { Holcus lanatus } \\
\text { Plantago lanceolata } \\
\text { Equisetum arvense }\end{array}$ & $\begin{array}{l}(2) \\
(1) \\
(1) \\
(1)\end{array}$ \\
\hline $\begin{array}{l}\text { 10. Baton Rouge, USA } \\
\left(30^{\circ} 25^{\prime} \mathrm{N}, 91^{\circ} 10^{\prime} \mathrm{W}\right)\end{array}$ & $\ddagger$ & $\begin{array}{l}\text { Andropogon glomeratus } \\
\text { Andropogon virginicus } \\
\text { Paspalum notatum } \\
\text { Sporobolus indicus }\end{array}$ & $\begin{array}{l}(3) \\
(2) \\
(1) \\
(2)\end{array}$ \\
\hline $\begin{array}{l}\text { 11. Minneapolis, USA } \\
\left(45^{\circ} 24^{\prime} \mathrm{N}, 93^{\circ} 12^{\prime} \mathrm{W}\right)\end{array}$ & $\ddagger$ & $\begin{array}{l}\text { Hedeoma hispida } \\
\text { Aristida basiramea } \\
\text { Ambrosia coronopifolia } \\
\text { Panicum oligosanthes }\end{array}$ & $\begin{array}{l}(1) \\
(1) \\
(1) \\
(1)\end{array}$ \\
\hline $\begin{array}{l}\text { 12. Sydney, Australia } \\
\left(33^{\circ} 56^{\prime} \mathrm{S}, 151^{\circ} 12^{\prime} \mathrm{E}\right)\end{array}$ & $\ddagger$ & $\begin{array}{l}\text { Cynodon dactylon } \\
\text { Pennisetum clandestinum } \\
\text { Chloris gayana } \\
\text { Stenotaphrum secundatum }\end{array}$ & $\begin{array}{l}(3) \\
(1) \\
(1) \\
(1)\end{array}$ \\
\hline
\end{tabular}

$\dagger 1=0-5 \%, 2=6-25 \%, 3=26-50 \%$ cover, $-=$ cover not recorded.

$\ddagger$ Neighbor biomass not recorded.

for Poa (e.g., grassland or old field) and where there was a productivity gradient due to within-site variation in factors such as soil depth, soil fertility, topography, or land use practices.

Cover of naturally occurring vascular plants at each site was recorded in $200.5 \times 1 \mathrm{~m}$ plots using the six class Daubenmire scale (Mueller-Dombois and Ellenberg 1974). Plots were chosen subjectively to account for variation in productivity (i.e., amount of vegetation present) at each site. A mean cover score was calculated for each species at each site.

\section{Experimental design and procedure}

At each site, an additional six plots, each $\approx 13 \mathrm{~m}^{2}$, were chosen subjectively, based on the amount of vegetation present, to include the range of within-site vari- 
ation in productivity. Plots were at least $30 \mathrm{~m}$ apart. Within each plot $100.5 \mathrm{~m}$ diameter subplots $(1 \mathrm{~m}$ apart) were chosen subjectively; 5 subplots were assigned randomly as controls (i.e., vegetation left intact) and 5 were treated in early spring with a contact herbicide (glyphosate [N-phosphenomethyl glycine], trade name Roundup) to remove vegetation. The herbicide was contained during application by enclosing the treated subplot in a $0.5 \mathrm{~m}$ diameter $\times 1 \mathrm{~m}$ tall metal cylinder that was held firmly to the ground. Possible translocation of herbicide was prevented by severing roots around the perimeter of each treated subplot to a depth of $15 \mathrm{~cm}$ with a shovel. Root severing was repeated in treated subplots at 3-wk intervals throughout the experiment to minimize invasion of roots of neighboring plants. Treated subplots were kept free of shoots of neighboring plants by hand-weeding. To exclude large herbivores such as rabbits, wire screening $(1.25 \mathrm{~cm}$ mesh, $33 \mathrm{~cm}$ tall) was placed around the perimeter of all subplots.

\section{Response to neighbor removal}

Seeds from a single seedlot of Poa pratensis var. Nassau were used for the experiment. Seeds were collected from plants grown in field plots at 1 of the 12 locations (i.e., Guelph, Canada). At each location, seeds were sown in $2.5 \times 2.5 \times 14 \mathrm{~cm}$ deep pots (Roottrainers, Spencer-Lemaire Industries, Alberta, Canada) that were filled with a 1:6 mixture of local soil : peat. After seeds germinated, seedlings were thinned to one per pot and they were grown in a greenhouse at each location to achieve a standard size (shoot mass of $0.1 \mathrm{~g}$ ) for transplanting into field plots. Seedling shoot mass was estimated using a regression equation in which shoot mass was the dependent variable and total leaf length and (or) leaf number were independent variables. At each location, the regression equation was constructed from data collected for 20 plants grown in the greenhouse together with transplants.

One seedling was transplanted into the center of each of the 60 subplots per location (10 subplots $\times 6$ plots). During the first $2 \mathrm{wk}$ after transplanting, seedlings were shaded by a $30 \times 40 \mathrm{~cm}$ piece of $70 \%$ shade cloth and were watered to minimize mortality. Dead seedlings were replaced during the first $3 \mathrm{wk}$ after transplanting.

After 10-12 wk, shoots of transplants and total aboveground biomass of neighbors in control plots were harvested, dried, and weighed. Belowground tissues were not harvested because of the practical difficulty of collecting small roots.

The relative growth rate (RGR) of each transplant was calculated as

$$
\mathrm{RGR}=\frac{\ln \left(M_{2}\right)-\ln \left(M_{1}\right)}{t_{2}-t_{1}},
$$

where $M_{2}$ is shoot mass at harvest, $M_{1}$ is estimated shoot mass at transplanting, and $t_{2}-t_{1}$ is the number of days between harvest date $\left(t_{2}\right)$ and transplanting date $\left(t_{1}\right)$. Mean RGR was calculated for treated and control subplots in each plot. For each site, the statistical significance of a difference between values of mean RGR for treated and control subplots was tested using Student's $t$ test. The total number of transplants surviving to the end of the experiment was also compared for treated and control subplots at each site. The statistical significance of a difference in transplant survival was tested using a $G$ test (Sokal and Rohlf 1981).

\section{Competition intensity}

Mean values of RGR were used to calculate both absolute competition intensity $\left(\mathrm{CI}_{a}\right)$ and relative competition intensity $\left(\mathrm{CI}_{r}\right) \cdot \mathrm{CI}_{a}$ was calculated as $\mathrm{RGR}_{t}-$ $\mathrm{RGR}_{c}$ and $\mathrm{CI}_{r}$ was calculated as $\left(\mathrm{RGR}_{t}-\mathrm{RGR}_{c}\right) / \mathrm{RGR}_{t}$, where $\mathrm{RGR}_{t}$ and $\mathrm{RGR}_{c}$ are the mean relative growth rates of transplants in treated subplots (i.e., neighbors removed) and control subplots (i.e., neighbors left intact), respectively.

For each index, CI values were first analyzed separately for each site to test the null hypothesis that CI was independent of neighbor biomass. Least squares linear regression was used to test the null hypothesis (i.e., slope of regression was not significantly different from zero $[P>0.05])$. CI values for all sites were then combined to test the null hypothesis that $\mathrm{CI}$ was independent of neighbor biomass over a wider range of neighbor biomass values. Generalized additive modelling (Hastie and Tibshirani 1990) was used to test for a statistically significant relationship between $\mathrm{CI}$ and neighbor biomass for all sites combined. This technique was chosen because it can be used for both linear modelling and nonlinear modelling. Our model contained a continuous predictor (neighbor biomass) as well as a categorical factor (site). If the relationship between the continuous predictor and the response is assumed to be linear, then the model is an analysis of covariance (ANCOVA), if nonlinear, a generalized additive model (GAM). In both cases, for the model to be interpretable, one has to assume a lack of interaction between effects of the continuous predictor and the categorical factor. This assumption was tested and verified.

In GAM, the most appropriate functional form of the relationship between the dependent variable and each independent variable is derived from the data using scatterplot smoothing (see Hastie and Tibshirani 1990 for details). The form of the model used here was

$$
Y=a+b_{s}+c f \text { (neighbor biomass) }+ \text { error, }
$$

where $a$ is the general intercept, $b_{s}$ is the intercept for site $s, c$ is a constant, and $f$ is a smoothing function for neighbor biomass. The constants $a, b_{s}$, and $c$ are estimated from the data. If $f$ is taken to be the identity function then the model reduces to a linear one (ANCOVA).

The statistical significance of a particular independent variable, neighbor biomass in this case, is assessed 
TABLE 2. Survival of Poa transplants in $n=6$ experimental plots.

\begin{tabular}{lccc}
\hline \hline & & & $\begin{array}{c}\text { Number } \\
\text { of plots } \\
\text { with low* } \\
\text { survival } \\
\end{array}$ \\
\cline { 2 - 3 } & $\begin{array}{c}\text { Number surviving } \\
(n=30)\end{array}$ & $\begin{array}{c}\text { Neighbors sub- } \\
\text { plots with } \\
\text { left }\end{array}$ & Neighbors \\
neighbors \\
Location & intact & removed & removed \\
\hline 1. Guelph & 21 & 30 & 0 \\
2. Almonte & 24 & 22 & 3 \\
3. Canberra & 25 & 28 & 0 \\
4. Morgantown & 15 & 15 & 3 \\
5. Vancouver & 25 & 24 & 2 \\
6. Umeå & 30 & 30 & 0 \\
7. Long Island & 26 & 24 & 1 \\
8. Sawyerville & 30 & 29 & 0 \\
9. Groningen & 24 & 25 & 1 \\
10. Baton Rouge & 6 & 1 & 6 \\
11. Minneapolis & 9 & 7 & 6 \\
12. Sydney & 7 & 7 & 6 \\
\hline
\end{tabular}

* Less than four of five transplants per subplot survived.

using the reduction in residual deviance $(D)$ attributable to a model with the variable included, as compared to a model excluding the variable. For our data, with an identity function and assumed Gaussian remainders, $D$ reduces to the remainder sum of squares (Hastie and Tibshirani 1990). A reduction in $D$ is tested for statistical significance by comparing the reduction in $D$ to a chi-square distribution with the degrees of freedom (df) for the simple model minus $\mathrm{df}$ for the more complex model. In this case, the simple model had site as the independent variable and the more complex model had both site and neighbor biomass as independent variables. In GAM, the degree of smoothing applied to fit a possibly nonlinear relationship can be controlled by setting the degrees of freedom for the continuous predictor; $\mathrm{df}=1$ specifies a linear fit, $\mathrm{df}=$ 5 specifies a very nonlinear fit. Whether the nonlinear fit is a significant improvement over the linear fit is tested in the usual way by comparing the two models. In this case, the statistical significance (i.e., $P$ values) of the variables neighbor biomass and site did not change appreciably when ANCOVA rather than GAM was used so only GAM results are reported here.

The proportion of variation $\left(R^{2}\right)$ accounted for by a particular GAM is calculated as the difference between $D$ for a model containing only a constant term (null model) and $D$ for the model under consideration, divided by $D$ for the null model.

Our analysis standardized for potential site effects on CI by modelling $\mathrm{CI}$ as the sum of a site factor plus a (possibly nonlinear) function of neighbor biomass. One index of competition intensity $\left(\mathrm{CI}_{r}\right)$ also standardized for potential site effects by expressing $\mathrm{CI}$ as a ratio. These two standardization procedures are complementary so GAM was used to test the null hypothesis for $\mathrm{CI}_{r}$ as well as for $\mathrm{CI}_{a}$.

\section{RESULTS}

\section{Neighbor biomass and species composition}

Neighbor biomass and species composition both varied considerably among sites (Table 1 ). Mean neighbor biomass per plot ranged from a low of $26-199 \mathrm{~g} / \mathrm{m}^{2}$ at Guelph to a high of $81-648 \mathrm{~g} / \mathrm{m}^{2}$ at Groningen. Vegetation was dominated by graminoids and forbs at each site but there was little overlap in dominant species among sites (Table 1). The target species Poa occurred naturally at four sites (Guelph, Vancouver, Umeå, and Groningen).

\section{Response to neighbor removal}

Transplant survival in subplots with neighbors left intact ranged from 6 to 30 plants of the 30 plants added per site (Table 2). Removing neighbors increased transplant survival significantly $(P<0.05, G$ test $)$ only at one site (Guelph).

Survival was low even in the absence of neighbors at some sites (Table 2). Drought and herbivores that were not excluded by the wire screening (e.g., insects, rodents) killed almost all transplants at three sites (Baton Rouge, Minneapolis, and Sydney). The same factors contributed to low survival in one to three of the six plots at each of five other sites (Almonte, Morgantown, Vancouver, Long Island, and Groningen). In total, 28 of the 72 plots, i.e., 6 plots $\times 12$ sites, had low survival of transplants in the absence of neighbors. Factors in addition to competition from neighbors probably limited transplant performance in these 28 plots so they were excluded from all subsequent analyses.

In the remaining 44 plots, mean RGR ranged from -0.016 to $0.024 \mathrm{~g} \cdot \mathrm{g}^{-1} \cdot \mathrm{d}^{-1}$ in subplots with neighbors left intact (Fig. 1). RGR was negative in 17 of 44 subplots because transplants lost mass during the experiment. In subplots with neighbors removed, mean RGR was positive in all cases and ranged from 0.003 to 0.056 $\mathrm{g} \cdot \mathrm{g}^{-1} \cdot \mathrm{d}^{-1}$

RGR was significantly $(P<0.05, t$ test) greater in subplots with neighbors removed than in subplots with neighbors left intact for 30 of the 44 plots (Fig. 1). At three sites (Guelph, Canberra, Umeå), removing neighbors increased RGR significantly in all plots. At other sites, removing neighbors increased RGR significantly only in plots with the most neighbor biomass (Morgantown, Groningen) or with the least neighbor biomass (Almonte, Vancouver) or with a medium to high amount of neighbor biomass (Long Island, Sawyerville).

\section{Competition intensity}

For all sites combined, the relationship between CI and neighbor biomass was not the same for $\mathrm{CI}_{a}$ (Fig. 2A) as for $\mathrm{CI}_{r}$ (Fig. 2B). $\mathrm{CI}_{a}$ increased significantly in a nonlinear fashion as neighbor biomass increased (Table 3 ). In contrast, $\mathrm{CI}_{r}$ did not change significantly as neighbor biomass increased. 


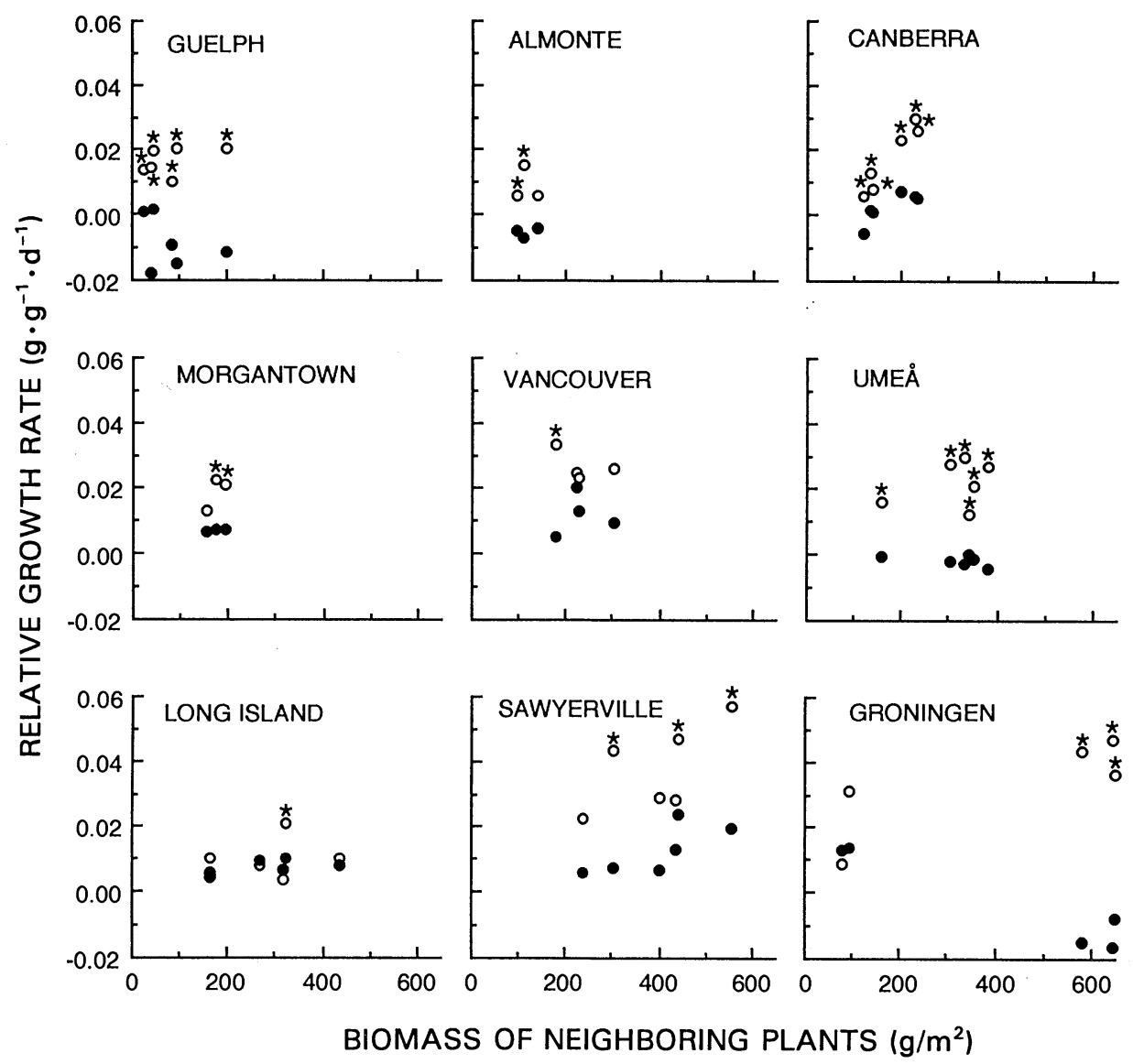

FIG. 1. Relationship between neighbor biomass and mean relative growth rate (RGR) for Poa transplants in subplots with neighbors removed $(O)$ or left intact $(\bullet)$ at each of nine sites. ${ }^{*} P<0.05$ for $t$ test comparing RGR values for subplots with neighbors removed vs. neighbors left intact at a particular value of neighbor biomass.

When sites were considered individually, $\mathrm{CI}_{a}$ increased significantly with increasing neighbor biomass only at Groningen $\left(P=0.025, R^{2}=0.85\right.$, linear regression). Similarly, $\mathrm{CI}_{r}$ increased significantly with increasing neighbor biomass only at Groningen $(P=$ $0.048, R^{2}=0.78$, linear regression).

\section{Discussion}

Our results show that competition from neighbors may reduce plant growth over a wide range of site productivity, including sites with even very low productivity. However, our results are only partly consistent with the null hypothesis that $\mathrm{CI}$ is independent of neighbor biomass. CI for Poa was independent of neighbor biomass over the relatively narrow range of values found at the majority of sites studied here, plus at two sites studied previously (DiTommaso and Aarssen 1991, Wilson and Tilman 1991). In contrast, CI was directly related to neighbor biomass at Groningen, where the range of neighbor biomass was greater than at any other site. Our finding that the relationship between $\mathrm{CI}$ and neighbor biomass may depend on the range of neighbor biomass considered is important for two reasons. First, it helps to explain why previous neighbor removal experiments, each involving a different range of habitat productivity, did not all detect the same relationship between CI and neighbor biomass. Second, it confirms that neighbor biomass is more likely to be a useful predictor of variation in CI over a wide range of habitat productivity than a narrow range. Moore and Keddy (1989) made a similar point about the utility of plant standing crop as a predictor of species richness. A predicted curvilinear relationship between species richness and plant standing crop was only evident over a wide range of plant standing crop, spanning different types of communities. Species richness and standing crop were unrelated within each community type.

Our inability to reject the null hypothesis for most sites may also reflect the relatively low number of degrees of freedom (i.e., 2-5) available for the statistical test at individual sites. Either a relatively large sample size or a large range of variation in neighbor biomass, or both, may be needed to detect any effect of neighbor biomass on CI.

Theories that predict that $\mathrm{CI}$ is unrelated to habitat 

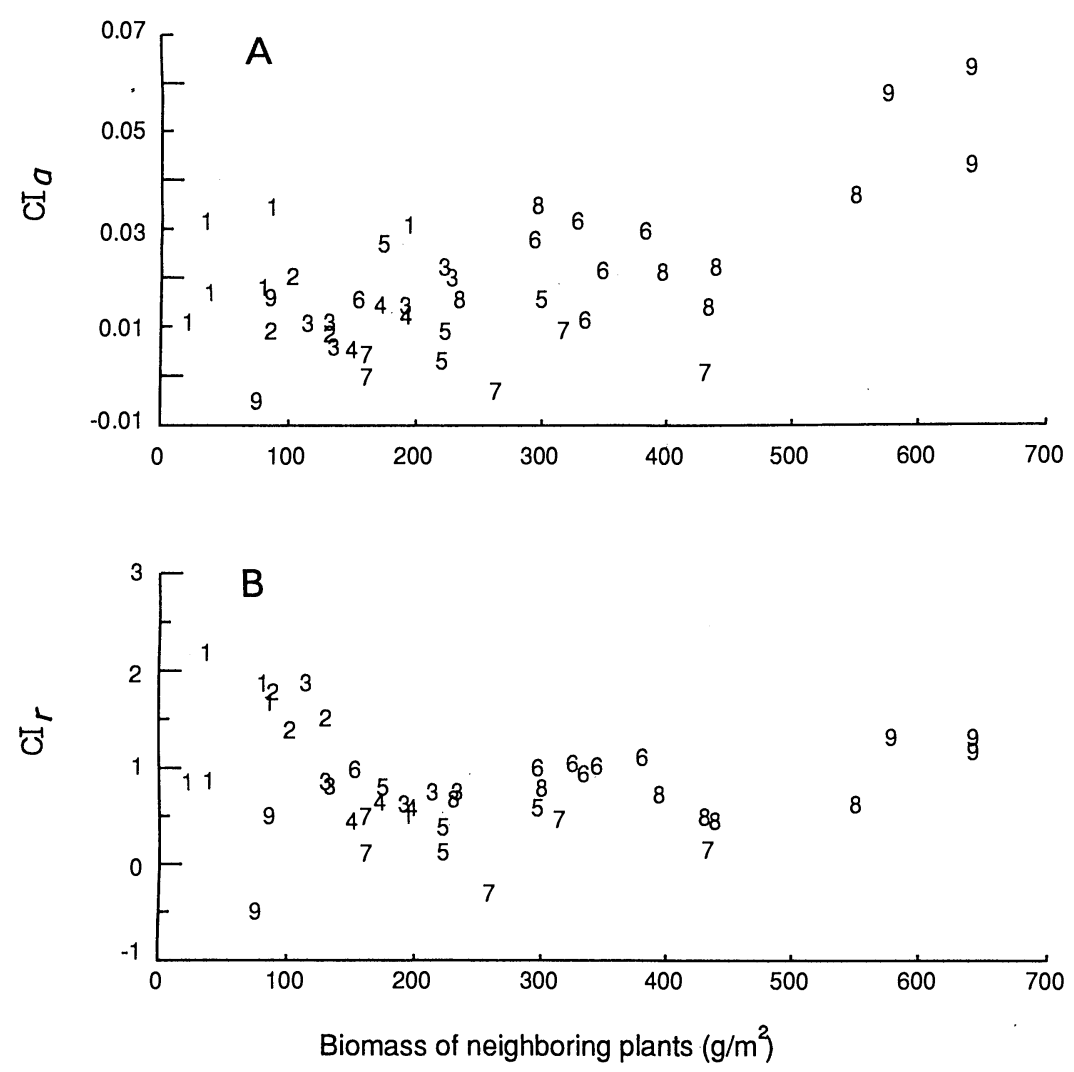

FIG. 2. Relationship between (A) neighbor biomass and absolute competition intensity $\left(\mathrm{CI}_{a}\right)$ and (B) neighbor biomass and relative competition intensity $\left(\mathrm{CI}_{r}\right)$ experienced by Poa transplants in 44 plots. Numbers 1 through 9 refer to site locations given in Table 1.

productivity (Tilman 1988, Taylor et al. 1990) are consistent with $P o a$ 's response to neighbor removal at sites with a narrow range of neighbor biomass but not at Groningen where there was a wider range of neighbor biomass. The reverse is true for theories that predict $\mathrm{CI}$ is directly related to habitat productivity (Grime 1979, Keddy 1990).

Attempts to test predicted relationships between CI and habitat productivity have been complicated by imprecise definition of $\mathrm{CI}$ and, consequently, by dis-

TABLE 3. Generalized additive model (GAM) results for all sites combined, with neighbor biomass (NB) and/or site (S) as independent variables and either absolute competition intensity $\left(\mathrm{CI}_{a}\right)$ or relative competition intensity $\left(\mathrm{CI}_{r}\right)$ as the dependent variable.

\begin{tabular}{|c|c|c|c|c|c|c|}
\hline \multirow{2}{*}{$\begin{array}{l}\text { De- } \\
\text { pen- } \\
\text { dent } \\
\text { vari- } \\
\text { able }\end{array}$} & \multirow{2}{*}{$\begin{array}{l}\text { Indepen- } \\
\text { dent } \\
\text { variables }\end{array}$} & \multirow[b]{2}{*}{$\mathrm{df}$} & \multirow[b]{2}{*}{$D^{*}$} & \multirow[b]{2}{*}{$R^{2}$} & \multicolumn{2}{|c|}{$\begin{array}{c}P \text { values for } \\
\text { independent } \\
\text { variables }\end{array}$} \\
\hline & & & & & $\mathrm{S}$ & NB \\
\hline$\overline{\mathrm{CI}_{a}}$ & $\mathrm{NB}+\underset{\mathrm{S}}{\mathrm{S}}$ & $\begin{array}{l}29 \\
34\end{array}$ & $\begin{array}{l}2524 . \\
5230 .\end{array}$ & $\begin{array}{l}0.70 \\
0.37\end{array}$ & $\begin{array}{l}<0.0001 \\
<0.002\end{array}$ & 0.0003 \\
\hline $\mathrm{CI}_{r}$ & $\mathrm{NB}+\underset{\mathrm{S}}{\mathrm{S}}$ & $\begin{array}{l}29 \\
34\end{array}$ & $\begin{array}{l}3.6 \\
5.6\end{array}$ & $\begin{array}{l}0.73 \\
0.58\end{array}$ & $\begin{array}{l}<0.0001 \\
<0.0001\end{array}$ & 0.35 \\
\hline
\end{tabular}

* $D=$ deviance, $R^{2}=$ fraction of variation explained. agreement about how CI should be measured and calculated (Welden and Slauson 1986, Campbell et al. 1991, Grace 1991). We measured CI by removing neighbors of a target plant since our objective was to help clarify inconsistent results of previous neighbor removal experiments. Campbell et al. (1991) questioned the use of removal experiments to study competition because nutrient supply in removal subplots may increase from decomposition of dead neighbors rather than just from reduced uptake of nutrients by neighbors. Both mechanisms reflect positive effects of neighbor removal on nutrient supply so this criticism is not entirely justified (cf. Aarssen and Epp 1990). At present, we do not know the relative importance of root decomposition vs. reduced nutrient uptake by neighbors for Poa's response to removal of its neighbors. The amount of nutrient released from decomposing roots would depend on their element content (e.g., N vs. P) and on abiotic conditions (Seastedt 1988, Eason and Newman 1990).

We calculated CI using two different indices and the choice of index affected the interpretation of results for all sites combined; $\mathrm{CI}$ and neighbor biomass were significantly related when $\mathrm{CI}$ was expressed in absolute terms $\left(\mathrm{CI}_{a}\right)$ but not in relative terms $\left(\mathrm{CI}_{r}\right)$. Campbell and Grime (1992) also found that $\mathrm{CI}_{a}$ was more sen- 
sitive than $\mathrm{CI}_{r}$ to a change in neighbor biomass. In both their study and ours, the absolute difference in plant mass (or RGR) with neighbors present vs. without neighbors present increased more rapidly than the relative difference. Since the choice of CI index may affect interpretation of results and different indices have been used in past studies, it is not surprising that study results have been inconsistent. Clarifying theoretical predictions about expected changes in both absolute and relative $\mathrm{CI}$ with habitat productivity may be useful.

In summary, our multisite study has demonstrated that competition from neighbors may influence plant growth over a wide range of site productivity and in this case there appeared to be no general relationship between $\mathrm{CI}$ and neighbor biomass.

\section{ACKNOWLEDGMENTS}

Poa seed was provided by the Department of Horticulture, University of Guelph. M. Austin, N. Fowler, P. Grubb, and J. P. Grime kindly commented on the experimental design. Financial support for the study was provided by the Australian Research Council, NSERC (Canada), NSF (USA), Research School of Biological Sciences of the Australian National University, and the Swedish Environmental Protection Agency.

\section{Literature Cited}

Aarssen, L. W., and G. A. Epp. 1990. Neighbour manipulations in natural vegetation: a review. Journal of Vegetation Science 1:13-30.

Campbell, B. D., and J. P. Grime. 1992. An experimental test of plant strategy theory. Ecology 73:15-29.

Campbell, B. D., J. P Grime, J. M. L. Mackey, and A. Jalili. 1991. The quest for a mechanistic understanding of resource competition in plant communities: the role of experiments. Functional Ecology 5:241-253.

del Moral, R. 1983. Competition as a control mechanism in subalpine meadows. American Journal of Botany $\mathbf{7 0}$ : 232-245.

DiTommaso, A., and L. W. Aarssen. 1991. Effect of nutrient level on competition intensity in the field for three coexisting grass species. Journal of Vegetation Science 2:513522.

Eason, W. R., and E. I. Newman. 1990. Rapid cycling of nitrogen and phosphorus from dying roots of Lolium perenne. Oecologia (Berlin) 82:432-436.

Fowler, N. L. 1990. The effects of competition and environmental heterogeneity on three coexisting grasses. Journal of Ecology 78:389-402.

Grace, J. B. 1991. A clarification of the debate between Grime and Tilman. Functional Ecology 5:585-587.

1993. The effect of habitat productivity on competition intensity. Trends in Ecology and Evolution 8:229 230.
Grime, J. P. 1979. Plant strategies and vegetation processes. J. Wiley \& Sons, Chichester, England.

Grubb, P. J. 1985. Plant populations and vegetation in relation to habitat, disturbance and competition: problems of generalization. Pages 595-611 in J. White, editor. The population structure of vegetation. Dr. W. Junk, Dordrecht, The Netherlands.

Gurevitch, J. 1986. Competition and the local distribution of the grass Stipa neomexicana. Ecology 67:46-57.

Hastie, T. J., and R. J. Tibshirani. 1990. Generalized additive models. Chapman and Hall, London, England.

Keddy, P. A. 1989. Competition. Chapman and Hall, London, England.

. 1990. Competitive hierarchies and centrifugal organization in plant communities. Pages 265-290 in J. Grace and D. Tilman, editors. Perspectives on plant competition. Academic Press, San Diego, California, USA.

Moore, D. R. J., and P. A. Keddy. 1989. The relationship between species richness and standing crop in wetlands: the importance of scale. Vegetatio 79:99-106.

Mueller-Dombois, D., and H. Ellenberg. 1974. Aims and methods of vegetation ecology. J. Wiley \& Sons, New York, New York, USA.

Newman, E. I. 1973. Competition and diversity in herbaceous vegetation. Nature 244:310-311.

Reader, R. J., and B. J. Best. 1989. Variation in competition along an environmental gradient: Hieracium floribundum in an abandoned pasture. Journal of Ecology 77:673-684.

Seastedt, T. R. 1988. Mass, nitrogen, and phosphorus dynamics in foliage and root detritus of tallgrass prairie. Ecology 69:59-65.

Sokal, R. R., and F. J. Rohlf. 1981. Biometry. Second edition. W. H. Freeman, New York, New York, USA.

Taylor, D. R., L. W. Aarssen, and C. Loehle. 1990. On the relationship between $\mathrm{r} / \mathrm{K}$ selection and environmental carrying capacity: a new habitat templet for plant life-history strategies. Oikos 58:239-250.

Tilman, D. 1988. Plant strategies and the dynamics and structure of plant communities. Princeton University Press, Princeton, New Jersey, USA.

Turkington, R., E. Klein, and C. P. Chanway. 1993. Interactive effects of nutrients and disturbance: an experimental test of plant strategy theory. Ecology 74:863-878.

Welden, C. W., and W. L. Slauson. 1986. The intensity of competition versus its importance: an overlooked distinction and some implications. Quarterly Review of Biology 61:23-44.

Wilson, S. D., and P. A. Keddy. 1986. Measuring diffuse competition along an environmental gradient: results for a shoreline community. American Naturalist 127:862-869.

Wilson, S. D., and J. M. Shay. 1990. Competition, fire, and nutrients in a mixed-grass prairie. Ecology 71:1959-1967.

Wilson, S. D., and D. Tilman. 1991. Components of plant competition along an experimental gradient of nitrogen availability. Ecology 72:1050-1065.

Wilson, S. D., and D. Tilman. 1993. Plant competition and resource availability in response to disturbance and fertilization. Ecology 74:599-611. 